\title{
ANÁLISE DAS QUESTÕES DO EXAME DE SUFICIÊNCIA DO CONSELHO FEDERAL DE CONTABILIDADE
}

\author{
Cleber Broietti ${ }^{1}$ \\ Rosimari Cristiane Evangelista ${ }^{2}$ \\ Hébila Mazaron ${ }^{3}$ \\ Mirian Aparecida Neris Fagundes Werner ${ }^{4}$
}

Resumo: O aumento no número de instituições de ensino superior que oferecem o curso de Ciências Contábeis fez o Conselho Federal de Contabilidade instituir o Exame de Suficiência. O estudo teve como objetivo comparar as questões desse exame com o conteúdo da Matriz Curricular de um curso de Ciências Contábeis de uma instituição de Ensino Superior Público localizado no Norte do Paraná e verificar se as disciplinas dessa matriz estão relacionadas com as questões do Exame. Foram analisadas as provas do Exame de Suficiência do ano de 2011 até o ano de 2014, as questões foram classificadas conforme as disciplinas do edital do exame. Os conteúdos que constam na matriz também foram classificadas conforme essas disciplinas. Após a análise de dados os resultados obtidos demonstram que a disciplina mais exigida é a de Contabilidade Geral e que a Instituição estudada apresenta em sua maioria disciplinas que tem carga horária compatível com a quantidade de questões exigidas no Exame.

Palavras-chave: Exame de Suficiência; Ciências Contábeis; Matriz Curricular.

\footnotetext{
${ }^{1}$ Ciências Contábeis/UNESPAR, Brasil, E-mail: cleberbroietti@gmail.com.

${ }^{2}$ Ciências Contábeis/UNESPAR, Brasil, E-mail: rosi-evangelista@hotmail.com.

${ }^{3}$ Ciências Contábeis/UNESPAR, Brasil, E-mail: hebila.m@hotmail.com.

${ }^{4}$ Ciências Contábeis/UNESPAR, Brasil, E-mail: mirianwerner@hotmail.com.
} 